\title{
ETIKA PENGGUNAAN MEDIA SOSIAL DALAM AL-QUR'AN SEBAGAI ALAT KOMUNIKASI DI ERA DIGITALISASI
}

\section{Husnah. Z}

Sekolah Tinggi Agama Islam Negeri Majene

Email: husnazainuddin25@gmail.com

\begin{abstract}
Abstrak
Artikel ini membahas tentang etika penggunaan media sosial yang dikaitkan dengan kandungan isi al-Qurán sebagai pedoman bagi setiap manusia. Media sosial telah menjadi alat komunikasi paling dibutuhkan di era globalisasi saat ini, sehingga dibutuhkan etika dalam penggunaannya. Dalam menggunakan media sosial sebaiknya mengacu pada al-Qur'an yang telah diwahyukan kepada Rasulullah Muhammad saw. Sebagai pedoman hidup bagi seluruh ummat manusia tentunya mampu menjadi sumber rujukan tertinggi. Dalam al-Qur'an terjelaskan etika berkomunikasi dengan media sosial yang tidak bertentangan dengan konstitusi Negara Indonesia.
\end{abstract}

Kata Kunci: Etika, Media Sosial, Komunikasi, ayat.

\section{A. PENDAHULUAN}

Komunikasi merupakan aktivitas azali manusia yang telah berlangsung sejak keberadaan manusia. Komunikasi Allah swt., dengan makhluk-makhluknya telah berlangsung dan sebagian terekam indah dalam media-media komunikasi (termasuk kitab suci). Tanpa komunikasi tidak mungkin kehidupan dapat berlangsung dan tidak mungkin pula peradaban manusia dapat berkembang. ${ }^{1}$ Untuk menggambarkan hal tersebut tidaklah berlebihan mengambil narasi dalam al-Qur'an terkait penciptaan Adam as. yang sejak penciptaannya langsung berdialog dengan Allah swt., yang menciptakannya dan para malaikat yang saat itu meragukan keberadaannya.

\footnotetext{
${ }^{1}$ Rachmat Kriyantono, Pengantar Lengkap Ilmu Komunikasi: Filsafat dan Etika Ilmunya Serta Perspektif Islam (Cet 1; Jakarta: Prenadamedia Group, 2019), h. 14.
} 
Sekaligus ini menandakan bahwa komunikasi merupakan keadaan pasti seiring eksistensi manusia itu sendiri.

Berbicara tentang konsep kekinian pola dan media komunikasi telah berkembang sedemikian ragamnya seiring dengan kemajuan teknologi informasi. Kemajuan teknologi ini telah memicu lahirnya ragam pola komunikasi baru yang sangat berbeda dengan sebelumnya yang terkadang bertabrakan dengan keumuman di suatu masyarakat. ${ }^{2}$ Misalnya hal tersebut dapat diperhatikan dari pola komunikasi seorang yang masih muda dengan seorang yang sudah berumur, yang dalam dialognya seorang yang lebih muda ini menggunakan kata "Anda" saat menyebut seseorang yang jauh lebih tua darinya. Dalam dialog tersebut kesan kesantunan dalam berkomunikasi seolah pudar. Pola komunikasi seperti ini berkembang karena hampir semua presenter televisi dalam berbagai acara dialog selalu menggunakan kata "Anda" kepada siapapun lawan bicaranya.

Konsep tentang komunikasi tidak hanya berkaitan dengan cara berbicara efektif saja melainkan juga berkaitan dengan etika berbicara. Semenjak memasuki era reformasi masyarakat Indonesia berada pada suasana euforia, bebas bicara tentang apa saja, terhadap siapapun, dengan cara bagaimana pun. Hal ini terjadi setelah masyarakat Indonesia mengalami kehilangan kebebasan bicara selama 32 tahun di masa orde baru. ${ }^{3}$ Pada era reformasi orang menemukan suasana kebebasan komunikasi sehingga tidak jarang cara maupun muatan pembicaraan tidak berlandaskan etika komunikasi yang terdapat dalam al-Qur'an. Bahkan, etika berkomunikasi yang mereka gunakan cenderung mengarah ke etika komunikasi ketimuran.

\section{B. PEMBAHASAN}

\section{Etimologi dan Epistimologi komunikasi}

${ }^{2}$ Zainul Maarif, Logika komunikasi (Cet 1; Jakarta: Rajawali Pers, 2015) h. 11.

${ }^{3}$ Nasaruddin Umar, Islam Fungsional "Revitalisasi dan Reaktualisasi Nilai-Nilai Keislaman" (Jakarta: Elex Media Komputindo, 2014), h. 129. 
Kata komunikasi dari aspek etimologi, berasal dari bahasa Yunani, yakni communicatio atau communis, yang berarti sama makna. ${ }^{4}$ Dari asal kata ini, dapat disimpulkan bahwa komunikasi mencakup kegiatan menyampaikan gagasan yang kemudian diterima dan dimaknai sehingga dimungkinkan terjadi saling pemahaman. Dari aspek terminologis, telah banyak definisi komunikasi yang disampaikan oleh para pakar. Bernard Berelson dan Gary A. Steiner mendefinisikan komunikasi sebagai transaksi informasi, gagasan, emosi, keterampilan, dan sebagainya, dengan menggunakan simbol-simbol, kata-kata, gambar, dan figur. Pendapat lain tentang definisi komunikasi juga dikemukakan oleh Carl Hovland, menurutnya komunikasi adalah proses yang memungkinkan seseorang menyampaikan rangsangan untuk mengubah perilaku orang lain. ${ }^{5}$

Sebagai proses yang terjadi dalam interaksi sosial, komunikasi bersifat dinamis, terus-menerus, dan kompleks. ${ }^{6}$ Komunikasi bersifat dinamis bermakna bahwa peristiwa komunikasi bersifat tidak tetap dan terus-menerus berubah dari waktu ke waktu. Sifat dinamis ini diakibatkan oleh motif, kepentingan, konteks sosial, dan kemampuan berkomunikasi yang juga berubah-ubah. Komunikasi bersifat terus-menerus bermakna bahwa komunikasi terjadi secara terus-menerus selama manusia hidup, dimulai sejak lahir dan terjadi dalam keseluruhan hidup manusia. Komunikasi bersifat kompleks karena komunikasi tidak terjadi di ruang hampa, tetapi akibat dipengaruhi oleh berbagai faktor kehidupan.

Secara epistimologi, riwayat perkembangan komunikasi antarmanusia adalah sama dengan sejarah kehidupan manusia itu sendiri. Ada empat titik penentu yamg utama dalam sejarah komunikasi manusia. Pertama, ditemukannya bahasa sebagai alat interaksi manusia. Kedua, berkembangnya seni tulisan dan kemampuan berbicara manusia menggunakan bahasa. Ketiga, berkembangnya kemampuan membuat kata-

\footnotetext{
${ }^{4}$ Rachmat Kriyantono, Pengantar Lengkap Ilmu Komunikasi: Filsafat dan Etika Ilmunya Serta Perspektif Islam, h. 156.

${ }^{5}$ Rachmat Kriyantono, Pengantar Lengkap Ilmu Komunikasi: Filsafat dan Etika Ilmunya Serta Perspektif Islam, h. 157.

${ }^{6}$ Zainuddin Maliki, Rekonstruksi Teori Sosial Modern (Cet 1; Yogyakarta: Gadjah Mada University Press, 2012), h. 17.
} 
kata tertulis dengan menggunakan alat pencetak, sehingga memungkinkan terwujudnya komunikasi massa yang sebenarnya. Keempat, lahirnya komunikasi elektronik, mulai dari telegraf, telepon, radio, televisi hingga satelit. ${ }^{7}$ Berkembangnya keempat titik penentu dalam sejarah komunikasi merupakan puncak prestasi peradaban manusia.

Komunikasi berkembang di seluruh negara yang ada di dunia, termasuk Indonesia. Perkembangan pesat dalam dunia komunikasi tentunya akan mengubah pola komunikasi yang terjadi di masyarakat selama ini. Sebelum ada media massa, nyaris sistem komunikasi yang berkembang di Indonesia masih menggunakan peralatan sederhana. Misalnya, dengan menggunakan media tradisional atau melalui komunikasi secara langsung. Setelah ditemukannya surat kabar, komunikasi sangat dipengaruhi kebenaran media cetak tersebut. Pada tahun 60-an, Televisi Republik Indonesia (TVRI) mengudara. Komunikasi yang dijalankan pun mengalami perubahan. Komunikasi melalui media elektonik (televisi) semakin mencapai puncaknya ketika di Indonesia sudah ada siaran televisi swasta nasional pada penghujung tahun $80-$ an. $^{8}$

Pola komunikasi terus berkembang, hingga Indonesia dikejutkan dengan pola komunikasi melalui Handphone. Media ini jelas akan mengubah perilaku komunikasi masyarakat. Komunikasi melalui Handphone adalah bentuk revolusi komunikasi di era digitalisasi yang sedang melanda Indonesia. ${ }^{9}$ Penggunaan alat komunikasi tersebut lebih digunakan untuk gaya hidup semata bukan untuk kebutuhan komunikasi. Fenomena komunikasi ini bahkan tidak mengindahkan etika penggunaannya. Hal ini dibuktikan dengan maraknya penyebaran berita bohong (hoax) yang meresahkan masyarakat dan berbagai perbuatan lainnya yang melanggar etika komunikasi.

\footnotetext{
${ }^{7}$ Burhan Bungin, Sosiologi Komunikasi: Teori, Paradigma, dan Diskursus Teknologi Komunikasi Di Masyarakat (Cet. 4; Jakarta: Prenada Media Group, 2009), h. 107.

${ }^{8}$ Nuruddin, Sistem Komunikasi Indonesia (Cet. 1; Jakarta: RajaGrafindo Persada, 2008), h. 189.

${ }^{9}$ Zainuddin Maliki, Rekomstruksi Teori Sosial Modern, h. 131.
} 


\section{Konsep Media Sosial dalam Al-Qur'an Sebagai Alat Komunikasi Di Era Digitalisasi}

Perkembangan teknologi komunikasi dalam industri IT nyaris melahirkan produk-produk baru setiap harinya, yang menyebabkan revolusi komunikasi adalah sesuatu yang tak terelakkan. Ia ibarat gelombang yang terus menggelora membentuk tatanan baru yang selalu mengarah dan berdasar pada logika teknologi. ${ }^{10}$ Saat ini, di era globalisasi akibat digitalisasi teknologi, perubahan masyarakat adalah suatu keniscayaan. Perubahan ini menyangkut berbagai aspek mendasar, termasuk terciptanya struktur dan identitas sosial baru.

Dewasa ini, teknologi informasi telah berkembang dengan pesat. Sehingga, melahirkan pola komunikasi baru yakni, dengan menggunakan media sosial. Di era digitalisasi, media memainkan peran yang sangat penting dalam menciptakan kesan. ${ }^{11}$ Apa yang nampak di media, baik media cetak maupun visual dapat diterima masyarakat luas sebagai suatu kebenaran. Meskipun masih ada beberapa pembaca dan pengamat yang bijak dan kritis melihat apa yang nampak di media sosial. Namun, ada juga pembaca dan pengamat yang tidak bijak dan kritis dalam menggunakan media sosial. Bahkan, menggunakan media sosial dengan sesuka hati dan tidak mematuhi etika penggunaannya yang telah terjelaskan dalam al-Qur'an.

Islam pun memberikan perhatian yang besar terhadap etika penggunaan media sosial. Hal ini dibuktikan dengan diaturnya etika penggunaan media sosial dalam alQur'an. Etika tersebut terdapat dalam al-Qur'an Surah al-Ahzab ayat 70.

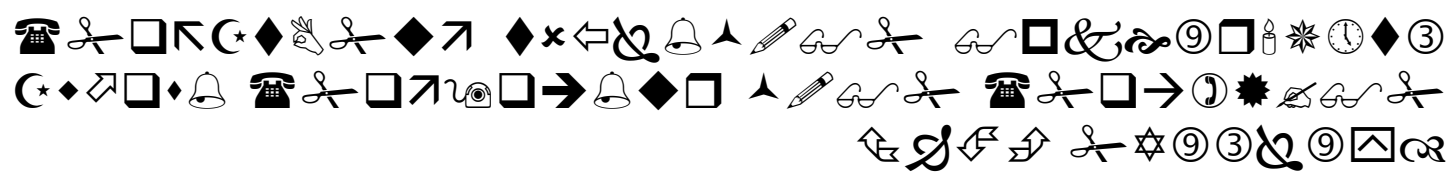

Terjemahnya:

"Hai orang-orang yang beriman, bertakwalah kepada Allah dan katakanlah perkataan yang benar." ${ }^{12}$ (QS. Al-Ahzab/33: 70)

\footnotetext{
${ }^{10}$ Zuly Qodir, Sosiologi Agama: Esai-esai Agama Di Ruang Publik (Cet. 1; Yogyakarta: Pustaka Pelajar, 2011), h. 128.

${ }^{11}$ Asghar Ali Engineer, Islam Masa Kini (Cet. 1; Yogyakarta: Pustaka Pelajar, 2004), h. 147.

${ }^{12}$ Kementrian Agama Republik Indonesia, Al-Qur'an dan Terjemahnya (Jakarta: Sinergi Pustaka Indonesia, 2012), 591.
} 
Kata sadidan terdiri dari huruf sin dan dal yang menurut pakar bahasa, Ibn Faris, menunjuk kepada makna meruntuhkan sesuatu kemudian memperbaikinya. Ia juga bermakna istiqamah/Konsisten. Kata ini juga digunakan untuk menunjuk kepada sasaran. ${ }^{13}$ Seorang yang menyampaikan sesuatu atau ucapan yang benar dan mengena tepat pada sasarannya dilukiskan dengan kata ini. Dengan demikian, kata sadidan dalam ayat di atas tidak sekedar berarti benar sebagaimana terjemahnya, tetapi ia juga harus berarti tepat sasaran. Dari kata tersebut diperoleh pula petunjuk bahwa kritik yang disampaikan hendaknya merupakan kritik yang membangun atau dalam arti informasi yang disampaikan haruslah baik, benar, dan mendidik.

Thahir Ibn Asyur menggarisbawahi kata qaul (ucapan) yang menurutnya merupakan satu pintu yang sangat luas, baik yang berkaitan dengan kebajikan maupun keburukan. ${ }^{14}$ Dengan perkataan yang tepat, baik yang terucap dengan lidah dan didengar oleh orang banyak maupun yang tertulis sehingga terucapkan oleh diri sendiri atau orang lain ketika membacanya akan tersebar luas dan memberi pengaruh bagi jiwa dan pikiran manusia. Jika ucapan itu baik, maka baik pula pengaruhnya dan jika ucapan itu buruk, maka buruk pula pengaruhnya. Ayat di atas menjelaskan bahwa dampak dari perkataan yang tepat adalah perbaikan amal-amal dan begitu pun sebaliknya.

Thabathaba'i berpendapat bahwa dengan keterbiasaan seseorang mengucapkan kalimat-kalimat yang benar, ia akan menjauh diri dari kebohongan dan juga akan terhindar dari perbuatan mengucapkan kata-kata yang mengakibatkan keburukan atau yang tidak bermanfaat. ${ }^{15}$ Seseorang yang telah memantapkan sikap tersebut pada dirinya, akan terhindar dari perbuatan-perbuatan yang mengandung kebohongan dan keburukan, dan ini berarti lahirnya amal-amal saleh dari yang

${ }^{13}$ M. Quraish Shihab, Tafsir Al-Misbah: Pesan, Kesan, dan Keserasian Al-Qur'an, Vol. 10 (Cet. 5; jakarta: Lentera Hati, 2012), h. 547.

${ }^{14}$ M. Quraish Shihab, Tafsir Al-Misbah: Pesan, Kesan, dan Keserasian Al-Qur'an, Vol. 10, h. 547. h. 548 .

${ }^{15}$ M. Quraish Shihab, Tafsir Al-Misbah: Pesan, Kesan, dan Keserasian Al-Qur'an, Vol. 10, 
bersangkutan. Ketika itu, ia akan menyadari menyadari betapa buruk amal-amal yang pernah ia lakukan. Sehingga ia akan bertobat kepada Allah swt.

Sebagai pedoman yang kompleks, al-Qur'an tidak hanya mengatur etika komunikasi menggunakan media sosial dalam satu ayat. Tetapi, ada beberapa ayat yang menjadi cerminan hal tersebut. Hal ini dapat dilihat dalam al-Qur'an surah alMujadalah ayat 9 .

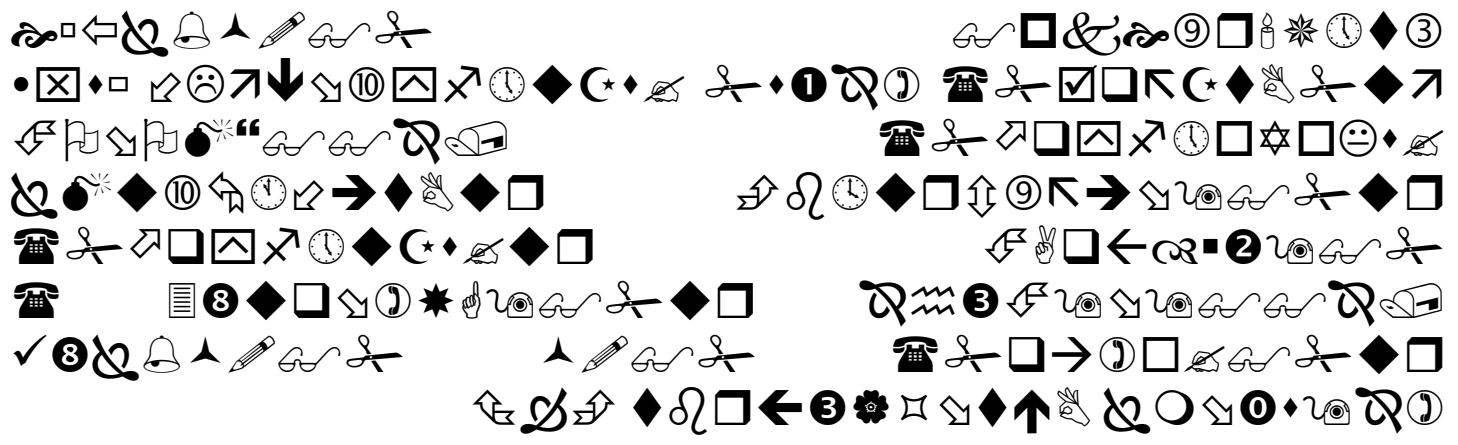

Terjemahnya:

"Wahai orang-orang yang beriman! Apabila kamu mengadakan pembicaraan rahasia, janganlah kamu membicarakan perbuatan dosa, permusuhan dan durhaka kepada Rasul. Tetapi bicaralah tentang perbuatan kebajikan dan takwa. Dan bertakwalah kepada Allah yang kepada-Nya kamu akan dikumpulkan kembali."16 (QS. Al-Mujadalah/58: 9)

M. Quraish Shihab dalam tafsir al-Misbah menjelaskan ayat di atas menyebut tiga ragam kedurhakaan, al-itsm (dosa), al-udwan (permusuhan), dan ma'shiyat arRasul (kedurhakaan kepada Rasul). Thabathaba'i membedakan masing masing hal di atas. Dosa dipahami dalam arti aktivitas yang membawa dampak buruk yang hanya mengenai pelakunya, seperti meminum minuman keras, berjudi, meninggalkan shalat, serta amal-amal yang berkaitan dengan hak-hak Allah swt. Permusuhan adalah aktivitas yang dampak buruknya merugikan diri sendiri dan juga orang lain, yang termasuk dalam hal ini adalah hak-hak manusia. Sedangkan yang dimaksud dengan

\footnotetext{
${ }^{16}$ Kementrian Agama Republik Indonesia, Al-Qur'an dan Terjemahnya, h. 793.
} 
kedurhakaan kepada Rasul adalah setiap perbuatan yang dilakukan dengan tidak mematuhi perintah atau larangan dari Rasulullah. ${ }^{17}$

Ayat tersebut memberi tuntunan kepada orang-orang beriman agar tidak membicarakan pembicaraan rahasia, seperti yang dilakukan oleh orang-orang Yahudi dan orang-orang yang ada penyakit dalam hatinya. ${ }^{18}$ Yakni, membicarakan tentang dosa, yaitu merencanakan atau melakukan perbuatan yang dapat berakibat buruk dan dapat menciptakan permusuhan serta kedurhakaan kepada Rasul. Jika seseorang memang harus melakukan pembicaraan rahasia dan tidak dapat menghindarinya, maka hendaknya hal yang dibicarakan secara rahasia merupakan perbuatan kebajikan yang dapat mendatangkan ketakwaan. Dengan begitu, manusia akan terhindar dari siksa Allah swt., baik berupa siksa duniawi maupun ukhrawi.

Ayat ini juga merupakan pendidikan yang sangat berharga bagi masyarakat. Karena ayat ini mengajarkan kepada masyarakat agar saling terbuka dan sedapat mungkin tidak merahasiakan sesuatu. ${ }^{19}$ Kerahasiaan mengandung makna ketidakpercayaan, sedangkan keterbukaan dan keterusterangan menunjukkan keberanian pembicara, keberanian atas dasar kebenaran dan ketulusan di hadapan orang lain. Ayat ini juga mengandung pelajaran yang sangat berharga menyangkut pembicaraan yang direstui agama., sekaligus mengingatkan bahwa amalan-amalan lahiriah hendaknya selalu disertai dengan keikhlasan serta keterbebasan dari tujuan duniawi yang sifatnya menggugurkan amalan itu. Oleh karena itu manusia harus bijak dalam menggunakan media sosial agar tidak menjadi ladang dosa. Melainkan media sosial tersebut dapat menjadi ladang pahala jika dimanfaatkan dengan benar.

\section{Etika Penggunaan Media Sosial Berdasarkan Tuntunan Al-Qur'an dan Konstitusi Negara Indonesia}

${ }^{17}$ M. Quraish Shihab, Tafsir Al-Misbah: Pesan, Kesan, dan Keserasian Al-Qur'an, Vol. 13 (Cet. 5; jakarta: Lentera Hati, 2012), h. 484.

${ }^{18}$ M. Quraish Shihab, Tafsir Al-Misbah: Pesan, Kesan, dan Keserasian Al-Qur'an, Vol. 13, h. 486 . h. 485 .

${ }^{19}$ M. Quraish Shihab, Tafsir Al-Misbah: Pesan, Kesan, dan Keserasian Al-Qur'an, Vol. 13, 
Kini dengan perkembangan luar biasa media komunikasi yang sedemikian canggih, manusia tidak hanya hidup dalam era revolusi komunikasi, tetapi tengah mengarungi era keberlimpahan komunikasi. Era keberlimpahan komunikasi ditandai oleh komunikasi yang melampaui ambang batas. ${ }^{20}$ Melimpahnya komunikasi dalam kehidupan tak lain karena ledakan informasi yang terus-menerus dibawa oleh media ke ruang-ruang kehidupan manusia kontemporer. Era keberlimpaham komunikasi ini justru dipandang telah membawa kontradiksi-kontradiksi baru dan menciptakan konflik-konflik baru di masyarakat.

Setiap agama memberikan perhatian yang besar terhadap aspek etis perilaku manusia. Perhatian yang besar ini diberikan karena etika memiliki peranan yang sangat penting untuk membentuk karakter moral yang berperan sebagai fungsi paling mendasar dari agama. Islam memiliki nilai etis dan konsep moralnya sendiri, baik yang bersifat spesifik maupun yang universal. ${ }^{21}$ Islam memiliki moralitas yang unik dan berbeda dengan agama yang lainnya. Islam juga sangat memperhatikan kesetaraan, keadilan, dan nasib seluruh umatnya. Etika Islam merupakan etika yang berdasar pada al-Qur'an dan perbuatan serta perkataan Nabi Muhammad saw., maka dari dua sumber tersebut seseorang akan dinilai baik dan buruk perbuatannya.

Islam memberikan perhatian yang besar terhadap etika komunikasi dengan menggunakan media sosial. Hal ini dibuktikan dengan diaturnya etika tersebut dalam al-Qur'an. Sebagai pedoman seluruh umat muslim al-Qur'an menjabarkan tentang etika tersebut dalam beberapa surah. Al-Ahzab ayat 9 menjelaskan bahwa dalam menggunakan media sosial, manusia harus mengucapkan perkataan yang benar karena perkataan merupakan pintu yang luas, dari pintu tersebut kebenaran ataupun keburukan dapat keluar. Oleh karena itu manusia harus membiasakan diri mengatakan perkataan yang benar agar terhindar dari perkataan yang dapat mendatangkan keburukan. Dalam surah al-Mujadalah ayat 9 dijelaskan pula etika

\footnotetext{
${ }^{20}$ Idi Subandy Ibrahim, Sirnanya komunikasi Empatik: Krisis Budaya Komunikasi dalam Masyarakat Kontemporer (Bandung: Pustaka Bani Quraisy, 2004), h. 29.

${ }^{21}$ Moch. Qasim Mathar, Sejarah, Teologi, dan Etika Agama-Agama (Cet. 1; Yogyakarta: Interfidei, 2003), h. 270.
} 
komunikasi yang lainnya. Surah tersebut menjelaskan bahwa dalam berkomunikasi manusia harus menghindari pembicaraan rahasia, apalagi pembicaraan yang mengandung dosa, permusuhan, dan kedurhakaan terhadap Rasul. Karena hal yang demikian akan membuat manusia merasakan siksaan Allah swt.

Komunikasi merupakan hal yang sangat penting bagi manusia. Oleh sebab itu tidaklah berlebihan jika komunikasi mendapat perhatian yang besar dari berbagai macam pihak termasuk pemerintah, utamanya komunikasi dengan menggunakan media sosial. Mengingat media sosial merupakan alat propaganda yang sewaktuwaktu dapat digunakan untuk menggiring opini masyarakat. Oleh karena itu, harus ada peraturan perundang-undangan yang mengatur tentang etika komunikasi. Untuk merealisasikan hal tersebut pemerintah mengeluarkan UU Nomor 19 Tahun 2016 tentang Informasi dan Transaksi Elektronik.

UU Nomor 19 Tahun 2016 merupakan Produk legislasi yang sangat dibutuhkan dan telah menjadi pionir dalam meletakkan dasar pengaturan dibidang pemanfaatan teknologi informasi. Aturan ini bertujuan untuk memberikan batasan kepada masyarakat agar tidak menggunakan media sosial secara sewenang-wenang dan untuk menjamin pengakuan serta penghormatan atas hak dan kebebasan orang lain. Dalam undang-undang tersebut dijelaskan tentang hal-hal yang tidak boleh dilakukan ketika menggunakan sosial media. Hal tersebut diatur dalam pasal 45A ayat (1).

"setiap orang yang dengan sengaja dan tanpa hak menyebarkan berita bohong dan menyesatkan yang mengakibatkan kerugian konsumen dalam Transaksi Elektronik sebagaimana dimaksud dalam pasal 28 ayat (1) dipidana dengan pidana penjara paling lama 6 (enam) tahun dan/atau denda paling banyak Rp1.000.000.000,00 (satu miliar rupiah).",22

Berdasarkan pasal tersebut maka pengguna media sosial tidak boleh menyebarkan berita bohong yang dapat menyesatkan masyarakat, apalagi sampai menimbulkan kerugian bagi orang lain, baik itu kerugian materi maupun non materi.

\footnotetext{
${ }^{22}$ Republik Indonesia, Amandemen Undang-Undang ITE: UU RI No. 19 Tahun 2016 tentang Informasi dan Transaksi Elektronik (Cet. 1; Jakarta: Redaksi Sinar Grafika, 2017), h. 13.
} 
Bahkan undang-undang memberikan sanksi kepada pengguna media sosial yang tidak mengindahkan etika penggunaannya. Sanksi yang diberikan berupa pidana penjara dan/atau denda dengan jumlah yang tidak sedikit.

Majelis Ulama Indonesia juga mengeluarkan aturan tentang etika komunikasi dengan menggunakan media sosial. Hal tersebut diatur dalam Fatwa Majelis Ulama Indonesia Nomor 24 Tahun 2017. Dalam fatwa tersebut dijelaskan bahwa pengguna media sosial dilarang untuk menyebarkan informasi yang tidak benar, hoax, fitnah, ghibah, namimah, ujaran kebencian, permusuhan dan hal terlarang lainnya yang dapat menyebabkan disharmoni sosial. ${ }^{23}$

\section{E. PENUTUP}

\section{Kesimpulan}

Berdasarkan pembahasan pada bagian sebelumnya maka penulis menyimpulkan kesimpulan sebagai berikut.

1. Secara etimologi komunikasi merupakan kegiatan menyampaikan gagasan yang kemudian diterima dan dimaknai sehingga dimungkinkan terjadi saling pemahaman. Sedangkan komunikasi secara epistimologi dapat dilihat dari berbagai aspek yang ada dalam komunikasi, misalnya dari sifat dan perkembangan komunikasi.

2. Media sosial sebagai alat komunikasi di era digitalisasi merupakan hal yang wajar. Karena dengan perkembangan teknologi komunikasi yang ada, maka sudah sewajarnya pola komunikasi mengalami perubahan. Dan al-Qur'an pun membenarkan hal tersebut. Namun dalam penggunakannya harus didasarkan pada tuntunan yang terjelaskan dalam al-Qur'an.

3. Dalam menggunakan media sosial kita harus mengacu pada al-Qur'an dan hukum positif yang ada di Negara Indonesia. Karena kedua aturan tersebut merupakan aturan yang tertinggi. Dalam al-Qur'an dan konstitusi Negara

\footnotetext{
${ }^{23}$ Majelis Ulama Indonesia, Fatwa Majelis Ulama Indonesia Nomor: 24 Tahun 2017 tentang Hukum dan Pedoman Bermuamalah Melalui Media Sosial (Jakarta: MUI, 2017), h. 1.
} 
Indonesia terjelaskan hal-hal yang boleh dan tidak boleh dilakukan ketika berkomunikasi dengan media sosial.

\section{Saran}

Bagi penulis yang ingin menulis tulisan dengan tema yang sama, sebaiknya mencari referensi yang lebih banyak agar tulisan yang dibuat dapat lebih baik lagi kedepannya karena referensi yamg digunakan lebih lengkap. 


\section{DAFTAR PUSTAKA}

Bungin, Burhan. Sosiologi Komunikasi: Teori, Paradigma, dan Diskursus Teknologi Komunikasi Di Masyarakat. Cet. 4; Jakarta: Prenada Media Group, 2009.

Engineer, Asghar Ali. Islam Masa Kini. Cet. 1; Yogyakarta: Pustaka Pelajar, 2004.

Ibrahim, Idi Subandy. Sirnanya komunikasi Empatik: Krisis Budaya Komunikasi dalam Masyarakat Kontemporer. Bandung: Pustaka Bani Quraisy, 2004.

Kementrian Agama Republik Indonesia. Al-Qur'an dan Terjemahnya. Jakarta: Sinergi Pustaka Indonesia, 2012.

Kriyantono, Rachmat. Pengantar Lengkapr Ilmu Komunikasi: Filsafat dan Etika Ilmunya Serta Perspektif Islam. Cet. 1; Jakarta: Prenadamedia Group, 2019.

Maarif, Zainul. Logika komunikasi. Cet 1; Jakarta: Rajawali Pers, 2015.

Majelis Ulama Indonesia. Fatwa Majelis Ulama Indonesia Nomor: 24 Tahun 2017 tentang Hukum dan Pedoman Bermuamalah Melalui Media Sosial. Jakarta: MUI, 2017.

Maliki, Zainuddin. Rekonstruksi Teori Sosial Modern. Cet 1; Yogyakarta: Gadjah Mada University Press, 2012.

Mathar, Moch. Qasim. Sejarah, Teologi, dan Etika Agama-Agama. Cet. 1; Yogyakarta: Interfidei, 2003.

Nuruddin. Sistem Komunikasi Indonesia. Cet. 1; Jakarta: PT. RajaGrafindo Persada, 2008.

Qodir, Zuly. Sosiologi Agama: Esai-esai Agama Di Ruang Publik. Cet. 1; Yogyakarta: Pustaka Pelajar, 2011.

Republik Indonesia. Amandemen Undang-Undang ITE: UU RI No. 19 Tahun 2016 tentang Informasi dan Transaksi Elektronik. Cet. 1; Jakarta: Redaksi Sinar Grafika, 2017.

Shihab, M. Quraish. Tafsir Al-Misbah: Pesan, Kesan, dan Keserasian Al-Qur'an. Vol. 10. Cet. 5; jakarta: Lentera Hati, 2012.

Shihab, M. Quraish. Tafsir Al-Misbah: Pesan, Kesan, dan Keserasian Al-Qur'an. Vol. 13. Cet. 5; jakarta: Lentera Hati, 2012. 
Umar, Nasaruddin. Islam Fungsional "Revitalisasi dan Reaktualisasi Nilai-Nilai Keislaman”. Jakarta: Elex Media Komputindo, 2014 